\title{
MODELING THE AGE OF THE CAPE RIVA (Y-2) TEPHRA
}

\author{
Sharen Lee ${ }^{1,2}$ - Christopher Bronk Ramsey ${ }^{1}$ Mark Hardiman $^{3}$ \\ ABSTRACT. Tephra from the Cape Riva (Y-2) eruption of Santorini has been found across the eastern Mediterranean. It pre- \\ sents an important link between marine and terrestrial records. A Poisson process (P Sequence) age-depth prior, with model \\ averaging, is used to model individual previously published radiocarbon sequences, cross-linked with an exponential phase \\ model parameter to obtain a robust age. Multiple sequences and ${ }^{14} \mathrm{C}$ determinations from 3 eastern Mediterranean data sets \\ (Seymour et al. 2004; Margari et al. 2009; Müller et al. 2011; Roeser et al. 2012) are used in the model. The modeled age of \\ the Y-2 tephra produced within this study is $22,329-21,088$ cal BP at $95.4 \%$ probability.
}

\section{INTRODUCTION}

The Cape Riva (also known as Y-2) eruption of the island of Santorini produced a widespread ash horizon that forms an important link between different marine and terrestrial environmental records across the eastern Mediterranean region. It is found in deep-sea sediments from the Black Sea (Kwiecien et al. 2008), Aegean Sea, and the Marmara Sea (Çağatay et al. 2000; Wulf et al. 2002; Aksu et al. 2008); in eastern Mediterranean deep-sea sediments near western Cyprus (Wulf et al. 2002); in terrestrial peat records in Greece (Seymour et al. 2004; Margari et al. 2007; Müller et al. 2011); and in a lake record in Turkey (Roeser et al. 2012). Obtaining an accurate age for this tephra is important because it is frequently used to date and correlate different marine and terrestrial chronologies (e.g. Çağatay et al. 2000; Kwiecien et al. 2008). Indeed, the Cape Riva has been included as part of the European INTIMATE Tephra Framework, representing a key candidate for allowing the precise synchronization of paleorecords (Davies et al. 2012). Despite this, no detailed modeled age range has thus far been developed.

\section{DATING}

Tephras can be directly dated using ${ }^{40} \mathrm{Ar} /{ }^{39} \mathrm{Ar}$ or indirectly dated using radiocarbon, usually of charred organic material found in the same context. They can also be dated relatively using annual laminations if they were found in varved sequences. Recent developments in ${ }^{40} \mathrm{Ar} /{ }^{39} \mathrm{Ar}$ dating have been shown to provide accurate and precise ages of young mafic volcanic rocks, with $1 \sigma$ uncertainties ranging from $0.5-2 \%$ (Lanphere 2000). Dating using the ${ }^{40} \mathrm{Ar} /{ }^{39} \mathrm{Ar}$ technique relies on the presence of K-rich minerals (sanidine or anorthoclase) in the form of either phenocrysts (Singer and Pringle 1996) or bulk crystals (Lanphere 2000). These materials are usually found in alkali-rich young tephras, and in coarse-grained, crystal-bearing proximal deposits. Hence, the applicability of the ${ }^{40} \mathrm{Ar} /{ }^{39} \mathrm{Ar}$ technique is limited (Blockley et al. 2008a). Unfortunately, the Y-2 tephra does not contain sanidine crystals for ${ }^{40} \mathrm{Ar} /{ }^{39} \mathrm{Ar}$ dating, nor has it yet been found in laminated sequences. Instead, ${ }^{14} \mathrm{C}$ was used previously to date the tephra.

The Y-2 tephra has several proposed ${ }^{14} \mathrm{C}$ ages from both marine and terrestrial environments. Interpolation between $2{ }^{14} \mathrm{C}$ dates in the marine record from Edremit Bay provided a calibrated age of 21,620 cal BP (Aksu et al. 2008) and another marine record from the Black Sea provided a ${ }^{14} \mathrm{C}$ determination of 19,770 BP (Kwiecien et al. 2008). Charred trees from the lower part of the terres-

\footnotetext{
${ }^{1}$ Research Laboratory for Archaeology and the History of Art, University of Oxford, Dyson Perrins Building, South Parks Road, Oxford OX1 3QY, United Kingdom.

${ }^{2}$ Corresponding author. Email: sharen.lee@oxfordalumni.org.

${ }^{3}$ Department of Geography, Royal Holloway, University of London, Surrey TW20 0EX, United Kingdom.
}

(C) 2013 by the Arizona Board of Regents on behalf of the University of Arizona Proceedings of the 21st International Radiocarbon Conference edited by A J T Jull \& C Hatté RADIOCARBON, Vol 55, Nr 2-3, 2013, p 741-747 


\section{S Lee et al.}

trial pumice flow have provided ${ }^{14} \mathrm{C}$ determinations of 18,050 $\pm 340,18,165 \pm 210$, and 18,880 \pm 230 BP (Pichler and Friedrich 1976). This is supported by Eriksen et al. (1990), who dated charcoal from small trees and branches covered by ignimbrites and provided a ${ }^{14} \mathrm{C}$ determination of $18,150 \pm$ 200 BP. Seymour et al. (2004) also provided ${ }^{14} \mathrm{C}$ determinations of 18,527 $\pm 145 \mathrm{BP}$ and 18,244 \pm $143 \mathrm{BP}$ below the Y-2 tephra layer as part of a tephrochronological record. In addition to the available ${ }^{14} \mathrm{C}$ dates, the $\mathrm{Y}-2$ tephra is found in 3 terrestrial ${ }^{14} \mathrm{C}$-dated paleoclimatic records from Lesvos Island (Margari et al. 2009) and Tenaghi Philippon (Müller et al. 2011), Greece, and a lake record in Turkey (Roeser et al. 2012).

\section{MODELING}

Bayesian analysis is a well-established tool for combining prior information with absolute dates to improve the precision and accuracy of archaeological and paleoenvironmental chronologies. A Bayesian framework is employed to estimate the precise age of the Y-2 tephra. Previous applications of Bayesian techniques in modeling tephra ages can be found in Blockley et al. (2008a,b), where the authors used a mixture of phase models, where related events are grouped together, and age-depth models to test the robustness, as well as enhancing the precision and accuracy, of published tephra ages. Only sequences that have the Y-2 tephra are included in the Bayesian model; the marine ${ }^{14} \mathrm{C}$ dates are not employed due to the uncertain marine reservoir offset.

Bulk sediments and plant macrofossils form the majority of ${ }^{14} \mathrm{C}$ samples for the record from the Megali Limni basin on Lesvos Island (ML01; Margari et al. 2009). The ML01 sequence (10.97 $\mathrm{m}$ in length) consists of $9{ }^{14} \mathrm{C}$ determinations; 2 of these are outside the limit of ${ }^{14} \mathrm{C}$ and are excluded from the model. The ML01 sequence also has evidence that suggests the presence of a hiatus between the ${ }^{14} \mathrm{C}$ dates in close proximity to the tephra, stratigraphically. Evidence includes an erosion surface at $1.29 \mathrm{~m}$, and also a significant transition to primarily inorganic sediments at $1.5 \mathrm{~m}$ (Margari et al. 2009). For these reasons, the ${ }^{14} \mathrm{C}$ determination, SUERC-1287 (1538 $\left.\pm 28 \mathrm{BP}\right)$, is also excluded from the model. The rest of the ML01 sequence is still reliable for modeling the age of the Y-2 tephra because it is found at $1.81 \mathrm{~m}$, which is below the erosion surface and the significant transition to inorganic sediments.

The Tenaghi Philippon sequence (14.62 m in length) consists of 20 and $12{ }^{14} \mathrm{C}$ determinations, respectively. The sequence was dated with bulk sediments, wood, and carbonates from shells (Müller et al. 2011). The Y-2 tephra is found at $7.61 \mathrm{~m}$ in the Tenaghi Philippon sequence (Müller et al. 2011).

Another widespread tephra, the Campanian Ignimbrite (CI), is also found in all of the above peat sequences. In addition to the 2 peat chronologies, ${ }^{14} \mathrm{C}$ determinations on bulk sediments underneath the Y-2 tephra layer are also available from the Philippi peat basin in Macedonia (Seymour et al. 2004). The CI (also known as Y-5) eruption is the largest known eruption of the last 100,000 yr (Barberi et al. 1978). This eruption has been located in the Campi Flegrei region of southern Italy, which is close to the present-day Bay of Naples. The ash horizon of this event is widespread and is recognized in cores across the eastern Mediterranean (Pyle et al. 2006). An extensive study of the age of this tephra yielded a high-precision ${ }^{40} \mathrm{Ar} /{ }^{39} \mathrm{Ar}$ age of $39,280 \pm 100 \mathrm{BP}$ (de Vivo et al. 2001) and this is the age recommended by Pyle et al. (2006) as the accepted geological age of this eruption. It is in good agreement with another ${ }^{40} \mathrm{Ar} /{ }^{39} \mathrm{Ar}$ age of this tephra $(41,100 \pm 2100 \mathrm{BP}$, Ton-That et al. 2001). The age of the Y-5 tephra can be integrated on its own and as a tie-point (point of equal age) into the 2 sequences described above to enhance the precision of the overall chronologies. 


\section{Modeling the Age of the Cape Riva (Y-2) Tephra}

The Lake Iznik sequence from Turkey $\left(6.83 \mathrm{~m}\right.$ in length) is the only sequence containing ${ }^{14} \mathrm{C}$ determinations from plant material. ${ }^{14} \mathrm{C}$ determinations from other materials (e.g. peat and shells) are also available, but only dates from plant materials are incorporated into the model because they provide the confidence that they relate securely to the context dated, with no reservoir effects. The Y-2 tephra is found at $13.89 \mathrm{~m}$ in the Lake Iznik sequence (Roeser et al. 2012).

There are many age-depth modeling programs freely available to researchers (e.g. Buck et al. 1999; Bronk Ramsey 2009; Blaauw and Christen 2011). Bronk Ramsey (2008) introduced a Poisson process (P Sequence) prior for modeling random deposition in primarily sequences with stratigraphic markers or annually laminated sequences. The P Sequence prior relies on the use of a model parameter for step size $(k)$ to define the increment in the model runs, which can be estimated using the variability in distances between the known-age layers. In non-annually laminated sequences with no stratigraphic marker layers, $k$ would have to be estimated using other means, such as the dating information or model agreement with the data (e.g. Blockley et al. 2007). These methods are not satisfactory since there are dangers of circular reasoning. Bronk Ramsey et al. (2010) discussed the use of a model averaging approach to overcome the subjectivity in model selection, and this method is implemented in the most recent OxCal version (Bronk Ramsey and Lee, these proceedings). This modified P Sequence prior is used here to model age-depth sequences.

Age-depth models are constructed for records from Lesvos Island, Tanaghi Philippon, and Lake Iznik using the P Sequence model, for estimating the age of the Y-2 tephra, because it provides the most realistic depiction of sedimentation for this case study, with the complexity (randomness) of the underlying sediment deposition modeled according to a Poisson process. The accelerator mass spectrometry (AMS) ages presented in Seymour et al. (2004) are also incorporated into the model using an exponential distribution as prior information. The exponential Tau Boundary is applied to the ${ }^{14} \mathrm{C}$ dates, as materials just underlying the tephra (Seymour et al. 2004: Figure 3) are most likely to be buried just before the eruption, but with a gradually decreasing probability of being from material deposited substantially earlier than the eruption. This approach had been previously used by Blockley et al. (2008b) to precisely estimate the age of the Neapolitan Yellow Tuff (NYT), with the Boundary parameter as a measure of the abrupt event.

Formal outlier analysis is not employed for this case study due to the good agreement between the ${ }^{14} \mathrm{C}$ likelihoods and the posterior model outputs (as determined by OxCal by agreement indices, $\mathrm{A}$, of $>60 \%$; Bronk Ramsey 1995). Tephra dispersal is considered as an abrupt event in terms of the uncertainty associated with absolute age measurements and so the same tephra horizons found in different sequences can be cross-linked to further enhance the precision of chronologies. This method is employed here to model the age of the Y-2 tephra.

\section{RESULTS AND DISCUSSION}

The posterior age-depth models for sequences in Lesvos, Tenaghi Philippon, and Lake Iznik are summarized in Table 1 and Figure 1. The modeled $k$ parameters for individual sequences are also shown in Figure 1. Posterior distributions for the exponential model are shown in Figure 2. The model yields a 95.4\% age range for the Y-2 tephra of 22,329-21,088 cal BP (Figure 3). This age range, although broad, is in good agreement with the combined ${ }^{14} \mathrm{C}$ ages, which is $22,200-21,411$ cal BP at $95.4 \%$ (Figure 4), on terrestrial plant material buried by ash for this tephra within their error ranges (Pichler and Friedrich 1976; Eriksen et al. 1990). 


\section{S Lee et al.}

Table 1 Calibrated and posterior ages for sequences in Lesvos, Tenaghi Philippon, and Lake Iznik; original data from Margari et al. (2009), Müller et al. (2011), and Roeser et al. (2012), respectively.

\begin{tabular}{|c|c|c|c|c|c|c|}
\hline \multirow[b]{2}{*}{ Sample } & \multirow[b]{2}{*}{${ }^{14} \mathrm{C}$ age } & \multirow{2}{*}{$\begin{array}{l}\text { Depth } \\
(\mathrm{m})\end{array}$} & \multicolumn{2}{|c|}{ Calibrated (BP) } & \multicolumn{2}{|c|}{ Modeled (BP) } \\
\hline & & & $68.2 \%$ & $95.4 \%$ & $68.2 \%$ & $95.4 \%$ \\
\hline \multicolumn{7}{|l|}{ Lesvos } \\
\hline $\mathrm{Y}-2$ & & 1.81 & & & $22,157-21,567$ & $22,329-21,088$ \\
\hline R_Date SUERC-5857 & $19,072 \pm 237$ & 1.836 & & $23,428-22,247$ & & \\
\hline ate SUERC & & 2.678 & & & $25,203-24,523$ & 325 \\
\hline ate SUERC-5 & $20,933 \pm 309$ & 3.974 & $385-24,517$ & & $25,966-25,220$ & 26,619 \\
\hline ate SUERC-5 & $27,781 \pm 743$ & 5.474 & $32,921-31,356$ & & $32,882-31,371$ & $34,121-31,080$ \\
\hline ate SUERC-31 & $32,304 \pm 1319$ & 6.677 & $38,640-35,397$ & $40,595-34,720$ & & $39,127-35,057$ \\
\hline R_Date SUERC-3032 & $41,384 \pm 4128$ & 11.628 & $48,412-43,106$ & $\ldots-41,814$ & $50,003-46,038$ & $50,003-43,391$ \\
\hline \multicolumn{7}{|l|}{ Tenaghi Philippon } \\
\hline R_Date Poz-15890 & 30 & 等 & & & & 26 \\
\hline ate Poz-15891 & & & & & & \\
\hline te Poz-15894 & $5790 \pm$ & 3.41 & & & & \\
\hline 44646 & $6350 \pm$ & 4.2 & & & & \\
\hline 44647 & $7600=$ & 4.59 & 843 & & & 330 \\
\hline $\mathrm{R}$ _Date $\mathrm{E}$ & $8820=$ & 5.56 & $10,118-9708$ & 10,15 & $10,123-9740$ & 10,15 \\
\hline R_Date Beta & $9890 \pm 60$ & 6.15 & $11,387-11,226$ & $11,602-11,200$ & $11,389-11,227$ & 11,60 \\
\hline R_Date Beta-244654 & $13570-$ & 6.98 & $16,851-16,642$ & $16,933-16,462$ & $16,854-16,648$ & 16,93 \\
\hline R_Date B & $16,560 \pm 90$ & 7.18 & $19,857-19,475$ & $20,034-19,442$ & 19,8 & 20,0 \\
\hline Y-2 & & 7.61 & & & $22,157-21,567$ & 22,32 \\
\hline R_Date Beta & $20,220 \pm 100$ & 8.2 & $24,307-23,966$ & $24,446-23,846$ & $24,311-23,972$ & 24,4 \\
\hline R_Date I & 23,3 & 8.86 & 28,36 & 28,5 & 28,345 & 28,5 \\
\hline R_Date B & $24,310 \pm 160$ & 9.3 & 29,424 & 28,582 & $29,380-28,854$ & 29,48 \\
\hline 244639 & $25,120 \pm 150$ & 9.85 & $30,215-29,741$ & $30,310-29,545$ & $30,225-29,772$ & $30,315-29,560$ \\
\hline-244640 & $27,760 \pm 190$ & 10.6 & & $32,581-31,419$ & $32,057-31,529$ & $32,505-31,420$ \\
\hline-244641 & $28,680 \pm$ & 11.25 & $33,500-32,746$ & $34,400-32,162$ & $33,566-32,823$ & $34,437-32,586$ \\
\hline 44642 & $32,390 \pm$ & 11.85 & 37,145 & $37,754-36$ & $37,049-36,550$ & $37,545-36,393$ \\
\hline & 35,290 & & & & & $41,172-39,618$ \\
\hline 44644 & $36,520 \pm$ & 13. & 41,8 & $42,201-40$ & 41,860 & $42,151-41,012$ \\
\hline R_D & & & & & 44,191 & $44,596-42,906$ \\
\hline R_Date Beta-2466 & $43,100 \pm 1200$ & 15.28 & $47,684-45,221$ & $49,369-44,735$ & $46,646-45,047$ & $48,037-44,484$ \\
\hline \multicolumn{7}{|l|}{ Lake Iznik } \\
\hline R_Date KIA & $230 \pm 60$ & & 9294-9091 & & & 94 \\
\hline $\mathrm{R}_{-}^{-} \mathrm{D}$ & & & 10 , & 10 & 10,2 & 10,3 \\
\hline-44588 & 12 & 10 & & 15,0 & 14,5 & 3,886 \\
\hline R_Date KIA-44591 & $13,450 \pm 100$ & 11.69 & $16,805-16,451$ & $16,893-15,960$ & $16,785-16,401$ & $16,869-15,956$ \\
\hline $\mathrm{Y}-2$ & & 13.89 & & & $22,157-21,567$ & $22,329-21,088$ \\
\hline
\end{tabular}

It is unfortunate that the Y-2 tephra is positioned at the edge of the ML01 sequence, providing little constraint on its age. This is also the reason for its low convergence $(<95 \%)$. Charred plant materials covered in ignimbrite (Eriksen et al. 1990) suggest that the sample was killed and charred by the volcanic event, which means that their ${ }^{14} \mathrm{C}$ determinations represent the time of the eruption; or that plant material were killed before charring, which means that their ${ }^{14} \mathrm{C}$ determinations represent a time before the eruption. Results from this paper imply that, on currently available dating evidence, the $95.4 \%$ probability modeled age range for the Y-2 tephra $(22,329-21,088$ cal BP) is the best calendar age estimate for the eruption.

The Poisson process model has proved useful in modeling sequences where high-precision chronological resolution is required. The model averaging approach has made a significant contribution to the modeling of the age of the Y-2 tephra in this study. It removes the subjectivity in model selection, and makes the model applicable and easier to use in sequences that are not annually laminated, in this case, peat sequences. 
Modeling the Age of the Cape Riva (Y-2) Tephra
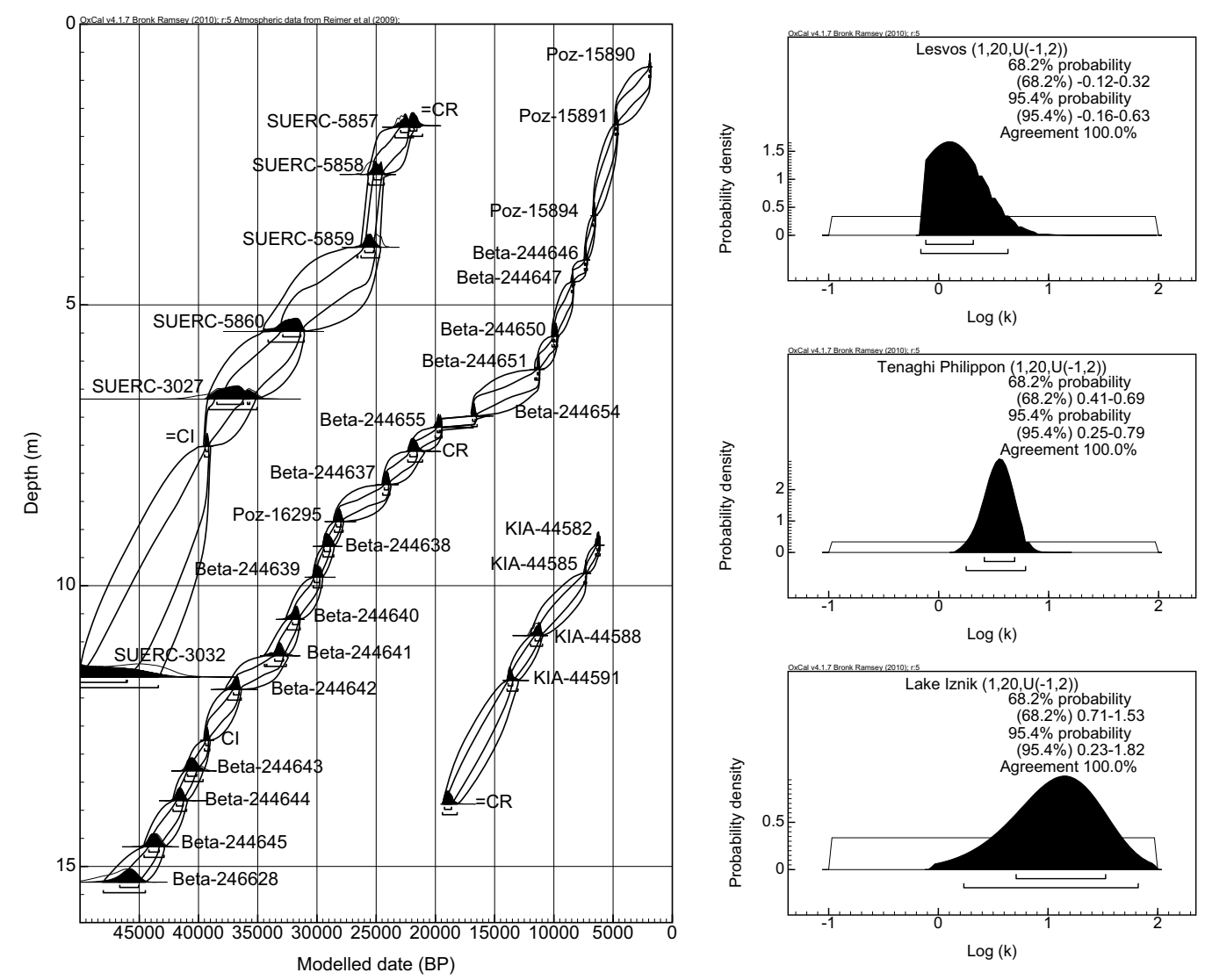

Figure 1 Posterior age-depth models for sequences in Lesvos (left), Tenaghi Philippon (middle), and Lake Iznik (right) and their corresponding modeled $k$ values, at $68.2 \%$ and $95.4 \%$ probability. Original ${ }^{14} \mathrm{C}$ data from Margari et al. (2009), Müller et al. (2011), and Roeser et al. (2012), respectively.

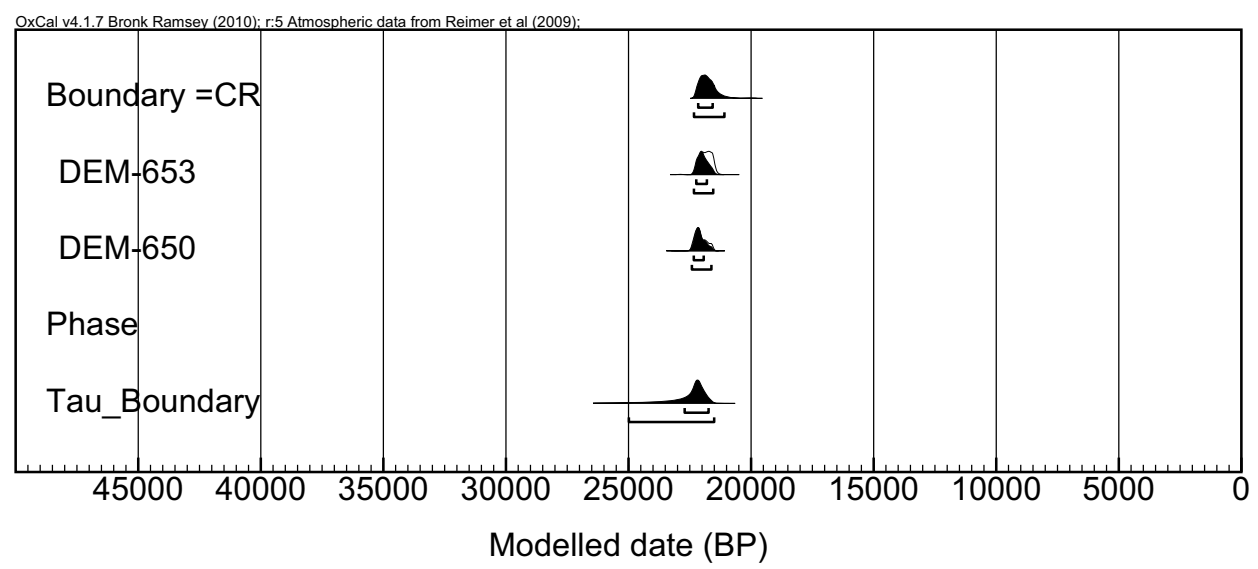

Figure 2 Posterior ages for the exponential phase model for the tephra ages from the Philippi peat basin in Macedonia (Seymour et al. 2004), at $68.2 \%$ and $95.4 \%$ probability. 


\section{S Lee et al.}

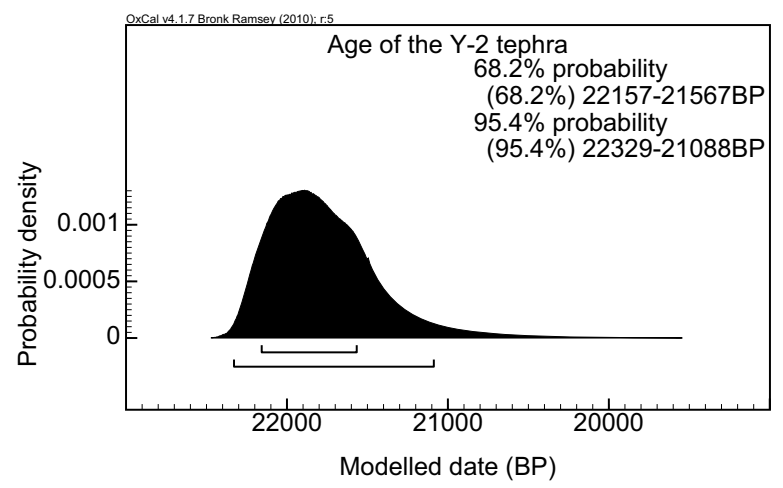

Figure 3 Posterior age of the Y-2 tephra, at $68.2 \%$ and $95.4 \%$ probability

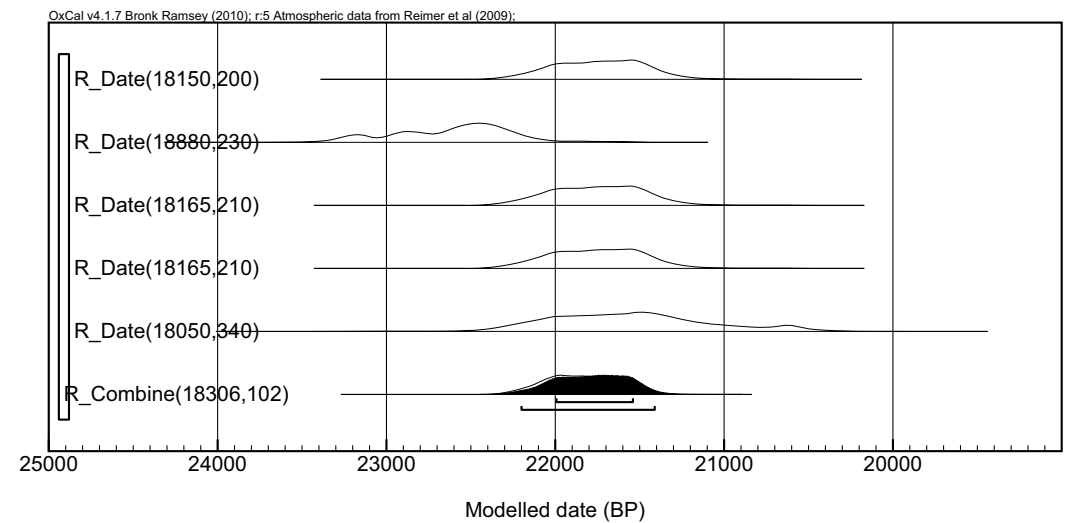

Figure 4 Published proximal ${ }^{14} \mathrm{C}$ ages of the Y-2 tephra from Pichler and Friedrich (1976) and Eriksen et al. (1990) in white and a combination of these ages in black.

Obtaining a robust calendar age for the Y-2 eruption is an important step in allowing the development of more precise absolute chronologies alongside the use of this tephra as an isochronous marker. The calendar age estimate put forward here would suggest the Cape Riva eruption occurred after the onset of GI-2 in the INTIMATE Event Stratigraphy (Blockley et al. 2012).

\section{ACKNOWLEDGMENTS}

The authors would like to thank Thomas Higham and Maarten Blaauw for comments. The research behind this paper was conducted in support of a NERC-funded project on Response of Humans to Abrupt Environmental Transitions (NE/E015670/1).

\section{REFERENCES}

Aksu AE, Jenner G, Hiscott RN, Isler EB. 2008. Occurrence, stratigraphy and geochemistry of Late Quaternary tephra layers in the Aegean Sea and the Marmara Sea. Marine Geology 252(3-4):174-92.

Barberi F, Innocenti F, Lirer L, Munno R, Pescatore TS, Santacroce R. 1978. The Campanian Ignimbrite: a major prehistoric eruption in the Neapolitan area (Italy). Bulletin of Volcanology 41(1):10-31.
Blaauw M, Christen JA. 2011. Flexible paleoclimate agedepth models using an autoregressive Gamma process. Bayesian Analysis 6(3):457-74.

Blockley SPE, Blaauw M, Bronk Ramsey C, van der Plicht J. 2007. Building and testing age models for radiocarbon dates in Lateglacial and Early Holocene sediments. Quaternary Science Reviews 26(15-16):191526. 


\section{Modeling the Age of the Cape Riva (Y-2) Tephra}

Blockley SPE, Bronk Ramsey C, Higham TFG. 2008a. The Middle to Upper Paleolithic transition: dating, stratigraphy, and isochronous markers. Journal of Human Evolution 55(5):764-71.

Blockley SPE, Bronk Ramsey C, Pyle DM. 2008b. Improved age modelling and high-precision age estimates of late Quaternary tephras, for accurate palaeoclimate reconstruction. Journal of Volcanology and Geothermal Research 177(1):251-62.

Blockley SPE, Lane CS, Hardiman M, Rasmussen SO, Seierstad IK, Steffensen JP, Svensson A, Lotter AF, Turney CS, Bronk Ramsey C, INTIMATE members. 2012. Synchronisation of palaeoenvironmental records over the last 60,000 years, and an extended INTIMATE event stratigraphy to 48,000 b2k. Quaternary Science Reviews 36:2-10.

Bronk Ramsey C. 1995. Radiocarbon calibration and analysis of stratigraphy: the OxCal program. Radiocarbon 37(2):425-30.

Bronk Ramsey C. 2008. Deposition models for chronological records. Quaternary Science Reviews 27(1-2): 42-60.

Bronk Ramsey C. 2009. Bayesian analysis of radiocarbon dates. Radiocarbon 51(1):337-60.

Bronk Ramsey C, Dee M, Lee S, Nakagawa T, Staff RA. 2010. Developments in the calibration and modeling of radiocarbon dates. Radiocarbon 52(2-3):953-61.

Bronk Ramsey C, Lee S. 2013. Recent and planned developments of the program OxCal. Radiocarbon, these proceedings, doi:10.2458/azu_js_rc.55.16215.

Buck CE, Christen JA, James GN. 1999. BCal: an online Bayesian calibration tool. Internet Archaeology. URL: http://intarch.ac.uk/journal/issue7/buck/.

Çağatay M, Görür N, Algan O, Eastoe C, Tchapalyga A, Ongan D, Kuhn T, Kuşcu I. 2000. Late Glacial-Holocene palaeoceanography of the Sea of Marmara: timing of connections with the Mediterranean and the Black Seas. Marine Geology 167(3):191-206.

Davies SM, Abbott PM, Pearce NJG, Wastegärd S. 2012. Integrating the INTIMATE records using tephrochronology: rising to the challenge. Quaternary Science Reviews 36:11-27.

de Vivo B, Rolandi G, Gans PB, Calvert A, Bohrson WA, Spera FJ, Belkin HE. 2001. New constraints on the pyroclastic eruptive history of the Campanian volcanic Plain (Italy). Mineralogy and Petrology 73(1):47-65.

Eriksen U, Friedrich WL, Buchardt B, Tauber H, Thomsen MS. 1990. The Stronghyle Caldera: geological, palaeontological and stable isotope evidence from radiocarbon dated stromatolites from Santorini. In: Hardy DA, editor. Thera and the Aegean World III. Volume 2. London: The Thera Foundation. p 139-50.
Kwiecien O, Arz HW, Lamy F, Wulf S, Bahr A, Röhl U, Haug G. 2008. Estimated reservoir ages of the Black Sea since the last glacial. Radiocarbon 50(1):99-118.

Lanphere M. 2000. Comparison of conventional K-Ar and ${ }^{40} \mathrm{Ar} /{ }^{39} \mathrm{Ar}$ dating of young mafic volcanic rocks. Quaternary Research 53(3):294-301.

Margari V, Pyle DM, Bryant C, Gibbard PL. 2007. Mediterranean tephra stratigraphy revisited: results from a long terrestrial sequence on Lesvos Island, Greece. Journal of Volcanology and Geothermal Research 163(1-4):34-54.

Margari V, Gibbard PL, Bryant CL, Tzedakis PC. 2009. Character of vegetational and environmental changes in southern Europe during the last glacial period; evidence from Lesvos Island, Greece. Quaternary Science Reviews 28(13-14):1317-39.

Müller UC, Pross J, Tzedakis PC, Gamble C, Kotthoff U, Schmiedl G, Wulf S, Christanis K. 2011. The role of climate in the spread of modern humans into Europe. Quaternary Science Reviews 30(3-4):273-9.

Pichler H, Friedrich W. 1976. Radiocarbon dates of Santorini volcanics. Nature 262(5567):373-4.

Pyle DM, Ricketts GD, Margari V, van Andel TH, Sinitsyn AA, Praslov ND, Lisitsyn S. 2006. Wide dispersal and deposition of distal tephra during the Pleistocene 'Campanian Ignimbrite/Y5' eruption, Italy. Quaternary Science Reviews 25(21-22):2713-28.

Roeser PA, Franz SO, Litt T, Ulgen UB, Hilgers A, Wulf S, Wennrich V, Ön SA, Viehberg FA, Çağatay MN, Melles M. 2012. Lithostratigraphic and geochronological framework for the paleoenvironmental reconstruction of the last $36 \mathrm{ka}$ cal BP from a sediment record from Lake Iznik (NW Turkey). Quaternary International 274:73-87.

Seymour KS, Christanis K, Bouzinos A, Papazisimou S, Papatheodorou G, Moran E, Dénès G. 2004. Tephrostratigraphy and tephrochronology in the Philippi peat basin, Macedonia, Northern Hellas (Greece). Quaternary International 121(1):53-65.

Singer BS, Pringle MS. 1996. Age and duration of the Matuyama-Brunhes geomagnetic polarity reversal from incremental heating analyses of lavas. Earth and Planetary Science Letters 139(1-2):47-61.

Ton-That T, Singer B, Paterne M. 2001. ${ }^{40} \mathrm{Ar} /{ }^{39} \mathrm{Ar}$ dating of latest Pleistocene (41 ka) marine tephra in the Mediterranean Sea: implications for global climate records. Earth and Planetary Science Letters 184(34):645-58.

Wulf S, Kraml M, Kuhn T, Schwarz M, Inthorn M, Keller J, Kuscu I, Halbach P. 2002. Marine tephra from the Cape Riva eruption (22 ka) of Santorini in the Sea of Marmara. Marine Geology 183(1):131-41. 